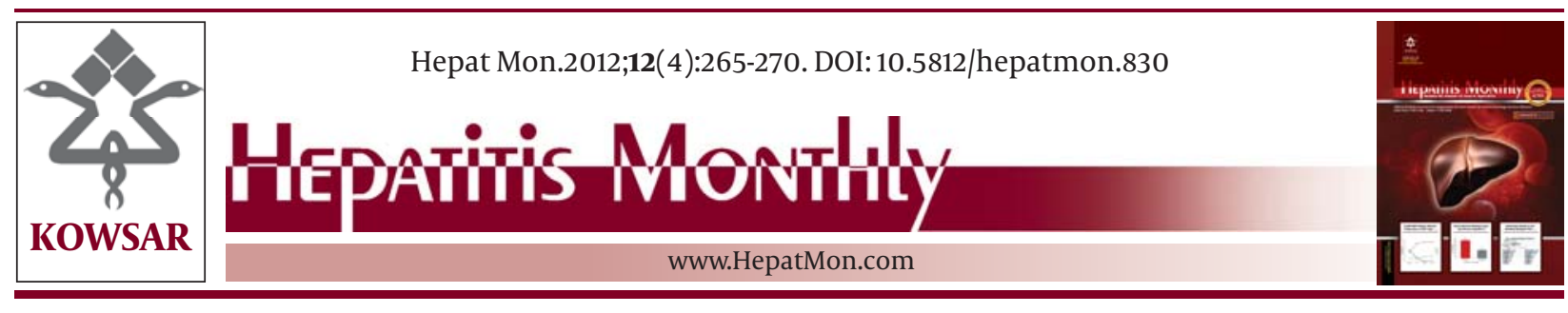

\title{
Evaluation of Multiplex Nested Polymerase Chain Reaction for Routine Hepatitis C Virus Genotyping in Egyptian Patients
}

\author{
Mohamed Abbas Shemis ${ }^{1}$, Dina Mohamed El-Abd ${ }^{2}$, Dalia Ibrahim Ramadan ${ }^{2}$, Mohamed \\ Ibrahim El-Sayed ${ }^{3}$, Bassem Shenoda Guirgis ${ }^{4}$, Mohamed Ali Saber ${ }^{1}$, Hassan Mohamed El- \\ Said Azzazy ${ }^{4,5}$ \\ ${ }^{1}$ Department of Biochemistry, Theodor Bilharz Research Institute, Giza, Egypt \\ ${ }^{2}$ Department of Clinical and Chemical Pathology, Faculty of Medicine, Cairo University, Cairo, Egypt \\ ${ }^{3}$ Department of Biochemistry, Faculty of Medicine, Cairo University, Cairo, Egypt \\ ${ }^{4}$ Yousef Jameel Science and Technology Research Center, the American University in Cairo, Cairo, Egypt \\ ${ }^{5}$ Department of Chemistry, the American University in Cairo, Cairo, Egypt
}

\begin{tabular}{l}
\hline A R T I C L E I N F O \\
\hline Article type: \\
Original Article \\
\hline Article history: \\
Received: 03 Nov 2011 \\
Revised: 24 Dec 2011 \\
Accepted: 25 Jan 2012 \\
\hline Keywords: \\
Hepatitis C \\
Multiplex Polymerase Chain Reac- \\
tion \\
Branched DNA Signal Amplification \\
Assay
\end{tabular}

\begin{abstract}
A B S T R A C T
Background: At least six HCV (hepatitis C virus) genotypes are unequally distributed worldwide. HCV genotyping guides the selection of treatment regimens and provides important epidemiological markers that enable the outbreak source to be traced and the spread of disease to be controlled. In Egypt, there is an increasing need for cost-effective, fast, and easily performable HCV genotyping assays.Recently, a multiplex PCR assay was developed to determine HCV genotypes. It employs genotype-specific primers, based on sequences of the entire core region and part of the 5'UTR of the genome.

objectives: In this study, we compared a simple, new, modified multiplex PCR system for HCV genotyping with a commercially available line probe assay (INNO-LiPA) that is based on reverse hybridization.

Patients and Methods: Serum samples from chronic HCV Egyptian patients ( $\mathrm{n}=73$ ) were genotyped using the modified multiplex PCR assay, and genotypes were verified using the INNO-LiPA HCV II assay.

Results: The modified multiplex PCR method was able to type HCV-4 in 65 of 70 typeable samples (92.86\%) and had $100 \%$ concordance with the INNO-LiPA assay.

Conclusions: Genotype 4 was the most prevalent genotype in our study. Based on our results, the modified multiplex nested PCR assay is a sensitive and inexpensive alternative for HCV genotyping and can be used in routine diagnostic laboratories. INNO-LiPA may be useful as a second-line assay for genotyping samples that are indeterminate by multiplex PCR. This approach will effect better treatment optimization and a reduction of the spread of HCV.

Copyright $\odot 2012$ Kowsar Corp. All rights reserved.
\end{abstract}

Implication for health policy/practice/research/medical education:

Egypt has the highest prevalence of worldwide HCV (15\%) and the highest prevalence of HCV-4, which is responsible for almost $90 \%$ of infections. There is increasing evidence that patients with different HCV genotypes have different clinical profiles, severity of liver disease and response to current combination therapy. HCV genotyping helps clinicians in their practice as it guides the selection of treatment regimens, and provides important epidemiological markers that enable outbreak source tracing and control of the spread of disease.

\section{- Please cite this paper as:}

Shemis MA, El-Abd DM, Ramadan DI, El-Sayed MI, Guirgis BS, Saber MA, et al. Evaluation of Multiplex Nested Polymerase Chain Reaction for Routine Hepatitis C Virus Genotyping in Egyptian Patients. Hepat Mon. 2012;12(4): 265-270. DOI: 10.5812/hepatmon.830

* Corresponding author: Dalia Ibrahim Ramadan, 21A, street 275, New

Maadi, 11435, Cairo, Egypt. Tel:+2-226771176, Fax:+2-22707367,

E-mail:dramadan7371@yahoo.com

DOI:10.5812/hepatmon.830

Copyright $\odot 2012$ Kowsar Corp. All rights reserved. 


\section{Background}

HCV genotype 4 (HCV-4) is responsible for more than $80 \%$ of HCV infections in the Middle East and Africa and has recently spread to several European countries $(1,2)$. Egypt has one of the highest rates of HCV worldwide $(\sim 15 \%)$ and the highest prevalence of HCV-4, which is responsible for nearly $90 \%$ of all infections $(1,3,4)$. Although phylogenetic analysis of a coding region, or even the complete genome, is considered to be the gold standard for identifying HCV genotypes and subtypes (5), this approach is impractical for large-scale genotyping projects, since it is both expensive and time-consuming $(6,7)$. Thus, a variety of surrogate HCV typing procedures have been developed over the past 10 years, based primarily on amplification of viral sequences by PCR. For all of these assays, only one region (eg, the 5'UTR, core) is analyzed as a representative of the entire genome (813). Examples of such assays include those developed by Okamoto et al. and Ohno et al. (10,11). One limitation of the assay by Okamoto et al. (1992) is that it was designed to detect genotypes 1, 2, and 3a (10). Thus, this system fails to type Egyptian strains, since no genotype 4-specific primers exist(14). Furthermore, the system also displays a higher number of mixed-infection designations, probably due to non-specific priming $(11,15)$.

A second example is the assay developed by Ohno et al. (1997) (11). However, it also needs to be revised or updated to enable new genotypesto be identified. In addition, the number of samples of genotypes 3, 4, 5, and 6 that were tested was very small and may not have been sufficient to allow definitive conclusions to be drawn about this method. Moreover, the region that was used to design outer primers might not be suitable if all common subtypes are to be detected with great sensitivity (15). In an attempt to overcome this limitation and increase the sensitivity of the assay, Idrees (2008) developed an assay that amplifies a region from the 5'UTR, along with the entire core region, using genotype-specific primers (15). Since the primers were designed based on the nucleotide sequences of many genotypes/subgenotypes-namely, 1a, 1b, 1c, 2a, 2b, 2c, 3a, 3b, 3c, 4a-h, 5a, and 6a HCV isolatesthis revised system has much broader applications.

\section{Objectives}

The main goal of this study was to evaluate a modified multiplex PCR system, based on that described by Idrees (2008), for use as a reliable and economical HCV genotyping method for Egyptian patients and to compare the results of this system with those obtained using a commercially available method that is based on the line probe assay, INNO-LiPA HCV II.

\section{Materials and Methods}

\subsection{Materials}

This study was conducted between January 2009 and
October 2009 and included 100 anti-HCV-positive serum samples collected from patients who were chronically infected with HCV. Anti-HCV was tested using a thirdgeneration enzyme immunoassay (EIA) (Murex Anti-HCV (Version 4) ABBOTT Diagnostic Division, Murex Biotech S.A. (Pty) Ltd, Kyalami Boulevard, and Republic of South Africa). Samples were taken from the Biochemistry Department of the Theodor Bilharz Research Institute and the Chemical Pathology Department of the Kasr Al-Aini Faculty of Medicine, Cairo University. The study was approved by the ethics committees from both hospitals.

\subsection{HCV RNA Extraction and PCR Detection}

HCV RNA was extracted from $140 \mu \mathrm{L}$ serum using the QIAamp Viral RNA Mini Kit (QIAgen, Hilden, Germany) and re-suspended in $60 \mu \mathrm{L}$ buffer. Strict measures were taken throughout the sampling, extraction, and PCR to prevent nucleic acid carryover (16). Nested reverse-transcription PCR (RT-PCR) was conducted, and HCV RNA-positive samples were genotyped.

\subsection{HCV Genotyping Using a Modified Multiplex PCR Protocol \\ 3.3.1. cDNA Synthesis and First-Round PCR Amplification}

In this study, we modified the multiplex PCR protocol reported by Idrees (15). The RT and first-round PCR were performed in a single step. Briefly, cDNA synthesis and first-round PCR amplification were performed in a $50 \mu \mathrm{L}$ reaction volume, containing $20 \mu \mathrm{L}$ RNA, 50 pmol of each of the universal outer forward and reverse primers (Table 1), $200 \mu \mathrm{M}$ of each deoxynucleotide (dNTP), $10 \mathrm{U}$ of avian myeloblastosis virus reverse transcriptase (AMV RT) (Promega Madison, WI, USA), 2.5 U of Taq DNA polymerase (Promega Madison, WI, USA), 40 U of RNAsin (Promega Madison, WI, USA), $20 \mathrm{mM}$ Tris- $\mathrm{HCl}$ (pH 8.4), and $50 \mathrm{mM}$ $\mathrm{KCl}$. Reactions were performed in a PTC 200 thermal cycler (MJ Research, Watertown, Mass., USA), programmed as follows: $42^{\circ} \mathrm{C}$ for $30 \mathrm{~min} ; 95^{\circ} \mathrm{C}$ for $5 \mathrm{~min} ; 40$ cycles of $94^{\circ} \mathrm{C}$ for $1 \mathrm{~min}, 45^{\circ} \mathrm{C}$ for $1 \mathrm{~min}$, and $72^{\circ} \mathrm{C}$ for 1 minute; and $72^{\circ} \mathrm{C}$ for $5 \mathrm{~min}$. This process amplified a $470 \mathrm{bp}$ band, which comprised part of the 5'UTR and the entire core region.

\subsubsection{Second-Round PCR}

Second-Round PCR was performed as in Idrees (15), in which 2 parallel second-round PCR reactions ( $20 \mu \mathrm{L}$ each) were conducted for each sample, using the first-round PCR amplicon and primer mixes A or B. Table 1 summarizes the universal and genotype-specific primers. Tubes were placed into a thermocycler that was programmed for 35 cycles as follows: 15 cycles $\left(94^{\circ} \mathrm{C}, 50^{\circ} \mathrm{C}\right.$, and $72^{\circ} \mathrm{C}$, for $45 \mathrm{~s}, 45 \mathrm{~s}$, and $1 \mathrm{~min}$ respectively); 20 cycles $\left(94^{\circ} \mathrm{C}, 58^{\circ} \mathrm{C}\right.$, and $72^{\circ} \mathrm{C}$, for $45 \mathrm{~s}, 45 \mathrm{~s}$, and $1 \mathrm{~min}$, respectively); and a final extension at $72^{\circ} \mathrm{C}$ for $10 \mathrm{~min}$. Amplicons were then resolved by agarose gel electrophoresis (2.5\%), yielding 
genotype-specific band sizes, which were compared with a 50 bp DNA ladder. The choice of primer combinations (mixes A and B) was decided, based on differences in genotype-specific band sizes. Figure 1 illustrates the multiplex PCR design.

\subsection{INNO-LiPA}

All samples were also analyzed by VERSANT HCV Genotype assay (INNO-LiPA HCV II; Bayer Health Care, Eragny, France) per the manufacturer's instructions (17).

\subsection{Statistical Analysis}

Data were analyzed using the SPSS, release 17.0. Categorical variables were expressed as rates (\%). Correlation and kappa test of agreement between the two assays were performed. $P$ values $\leq 0.05$ were considered statistically significant.

\section{Results}

Of the 100 serum samples that tested positive for antiHCV, 73 (73\%) specimens were found to be positive by RTPCR. There was a predominance of males among HCV RNA-positive patients: 58/73 (79.5\%) males versus 15/73 (20.5\%) females. Out of 73 RNA-positive samples, 70 (96\%) were successfully genotyped by the modified multiplex PCR system; the remaining 3 samples (4\%) were nontypeable (all male patients). Of the 70 typeable samples, 55 (79\%) were from male patients, while 15 (21\%) were from female patients. Typeable samples were distributed as follows: 1 was genotype 1a (1.43\%); 1 was genotype $1 \mathrm{~b}$ (1.43\%); 3 were genotype 3a (4.28\%); and 65 were genotype 4 (a-h) (92.86\%). Figure 2 shows genotype-specific bands byagarose gel electrophoresis. By INNO-LiPA assay, 72/73 (98.6\%) samples were successfully genotyped: 57/72 (79\%) were males versus 15/72 (21\%) females. Only 1 of $73(1.4 \%)$, a male patient, was non-typeable. Typeable samples had the following distribution: 1 was genotype $1 \mathrm{a}(1.4 \%) ; 1$ was genotype $1 \mathrm{~b}(1.4 \%) ; 3$ were genotype $3 \mathrm{a}(4.2 \%)$; 38 were

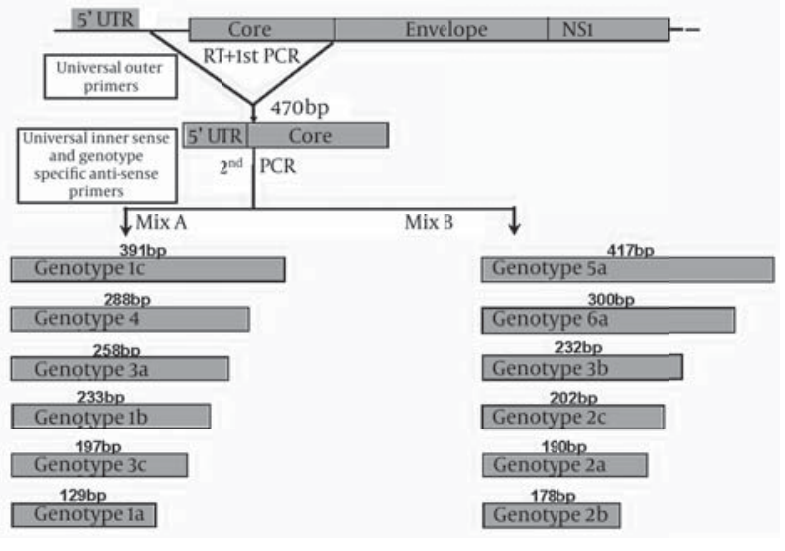

Figure 1. Schematic Design of the Modified Multiplex PCR Assay for HCV Genotyping
Figure 2. Agarose Gel Electrophoresis of the Modified Multiplex PCR Genotyping Method Showing Genotype-Specific Bands

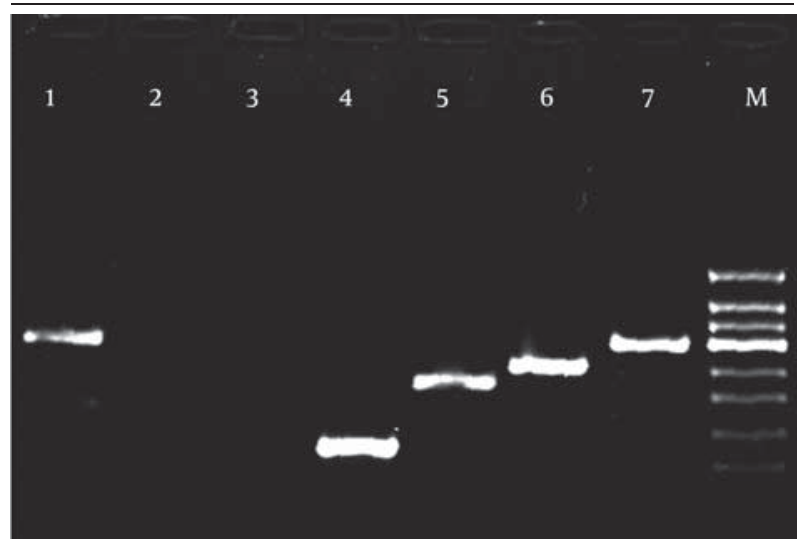

Lane 1 and 7: genotype 4 (288 bp); Lane 2: negative control; Lane 3: nontypeable; Lane 4: genotype 1a (129 bp); Lane 5: genotype $1 \mathrm{~b}$ (233 bp); Lane 6: genotype 3a (258 bp); M: DNA ladder (50 bp)

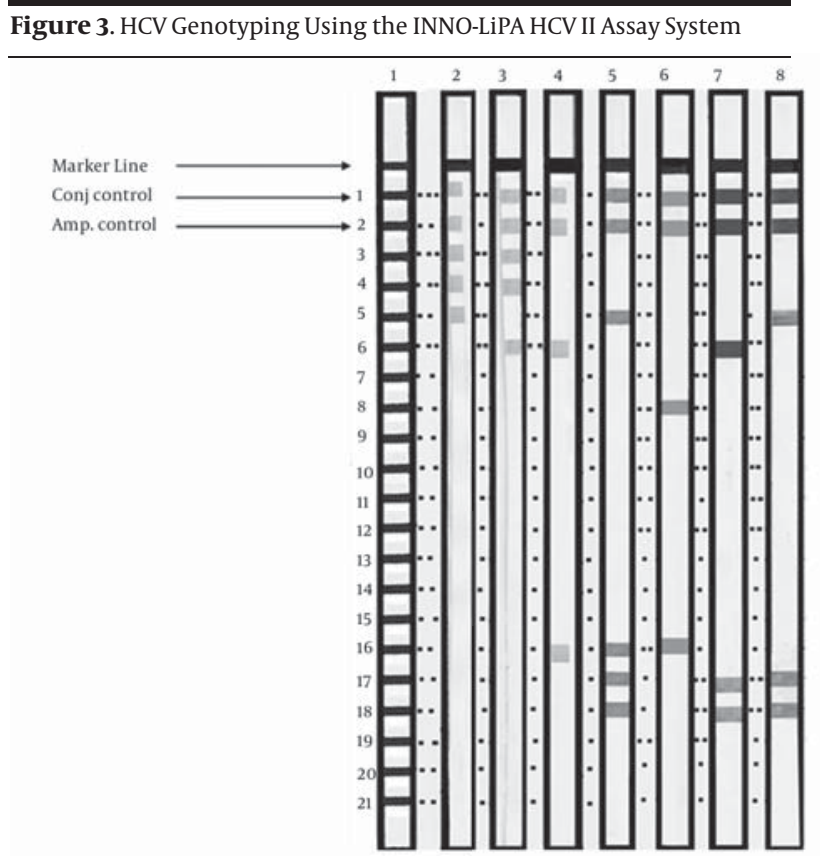

Lane 1: reference; Lane 2: genotype 1a; Lane 3: genotype 1b; Lane 4: genotype 4a; Lane 5: genotype 4c/d; Lane 6: genotype 4e; Lane 7: genotype 4h; Lane 8: genotype 4

genotype 4 (52.8\%); 2 (2.8\%) were genotype $4 \mathrm{a} ; 18$ were genotype $4 \mathrm{c} / 4 \mathrm{~d}(24.9 \%) ; 5$ were genotype $4 \mathrm{e}(6.9 \%)$; and 4 were genotype $4 \mathrm{~h}(5.6 \%)$. Figure 3 shows a sample of INNO-LiPA HCV II results. Based on a comparison of the results of both assays (Table 2), the genotypes of samples that were typeable by the modified multiplex PCR method were the same as those typed by the INNO-LiPA assay (100\% concordance). Of the 3 samples that were not typeable by the first assay, 2 were typeable by the second: 1 


\begin{tabular}{|c|c|c|c|}
\hline PCR rounds & Sequence $^{\mathrm{a}}$ & Specificity & Polarity \\
\hline \multirow[t]{2}{*}{ RT \& first PCR } & TTG TGG TAC TGC CTG ATA GGG & Universal outer & Sense \\
\hline & GGA TGT ACC CCA TGA GG(A) TCG & Universal outer & Anti-sense \\
\hline \multirow[t]{7}{*}{ Second PCR (Mix A) } & GTG CCC CGG GAG GTC TCG TAG & Universal inner & Sense \\
\hline & ACT CCA CCA ACG ATC TGA CC & Type 1a & Anti-sense \\
\hline & AGC CTT GGG GAT AGG TTG TC & Type 1b & Anti-sense \\
\hline & CTT ACC CAA ATT GCG TGA CC & Type 1c & Anti-sense \\
\hline & ACT CCA CCA ACG ATC TGT CC & Type 3a & Anti-sense \\
\hline & GTG ACC GCT CGG AAG TCT TA & Type 3c & Anti-sense \\
\hline & CCG TAA AGA GGC CAT GGA TA & Type 4 & Anti-sense \\
\hline \multirow[t]{7}{*}{ Second PCR(Mix B) } & GTG CCC CGG GAG GTC TCG TAG & Universal inner & Sense \\
\hline & CTC CGA AGT CTT CCT TGT CG & Type 2a & Anti-sense \\
\hline & AGC AAG TAA ACT CCG CCA AC & Type 2b & Anti-sense \\
\hline & ACC GTT CGG AAG TTT TCC TC & Type 2c & Anti-sense \\
\hline & AGC CTT GGG GAT AAG GTG AC & Type 3b & Anti-sense \\
\hline & AAT CCG CAC GTT AGG GTA TG & Type 5a & Anti-sense \\
\hline & CAG CCT TCG CTT CCA TAA AG & Type 6a & Anti-sense \\
\hline
\end{tabular}

${ }^{\mathrm{a}}$ Nucleotide inside parentheses is a degenerate nucleotide

\begin{tabular}{|c|c|c|c|c|}
\hline \multirow[t]{2}{*}{ HCV Genotype } & \multicolumn{2}{|c|}{ Modified Multiplex PCR Method (Genotype Specific Primers) } & \multicolumn{2}{|c|}{ INNO-LiPA HCV II (Line Probe Assay) } \\
\hline & Isolates, No. & Percentage & Isolates, No. & Percentage \\
\hline 1a & 1 & 1.37 & 1 & 1.37 \\
\hline $1 \mathrm{~b}$ & 1 & 1.37 & 1 & 1.37 \\
\hline $3 a$ & 3 & 4.11 & 3 & 4.11 \\
\hline 4 & 65 & 89.04 & 38 & 52.05 \\
\hline $4 a$ & - & - & 2 & 2.74 \\
\hline $4 c / 4 d$ & - & - & 18 & 24.66 \\
\hline $4 \mathrm{e}$ & - & - & 5 & 6.85 \\
\hline $4 \mathrm{~h}$ & - & - & 4 & 5.48 \\
\hline Not Genotyped & 3 & 4.11 & 1 & 1.37 \\
\hline Total & 73 & 100 & 73 & 100 \\
\hline
\end{tabular}

was typed genotype 4 and the other was typed $4 \mathrm{c} / 4 \mathrm{~d}$. The genotype of 1 sample was non-typeable by either assay. A significant positive correlation was observed between both methods ( $\mathrm{r}=0.874, P<0.001)$. By kappa test, there was excellent agreement (kappa $=0.848$ ) in the results between the two assays.

\section{Discussion}

There is increasing evidence that patients who are infected with different HCV genotypes have disparate clinical profiles, liver disease severities, and responses to current combination therapy. Hence, a convenient and reliable genotyping system is essential for large-scale epidemiological and clinical studies $(18,19)$. Although
HCV-4 is the cause of approximately $20 \%$ of the 170 million cases of chronic hepatitis $\mathrm{C}$ worldwide, it has not been the subject of significant research; thus, the features of this genotype and management strategies for patients who have been infected with this genotype are not as well developed as for genotypes 1, 2, and 3 (20). HCV-4 is a very heterogeneous genotype that displays significant genetic divergence and more subtypes than other genotypes. To date, 18 subtypes have been identified $(21,22)$. However, the full clinical significance of HCV4 subtypes is not known, because few studies have been conducted on the correlation between HCV-4 subtypes and the natural history of the disease, pathogenicity, disease severity, and therapeutic outcomes $(23,24)$. In this study, HCV chronic hepatitis was more frequent in males 
over females (3.9:1), confirming earlier reports (14, 2530). This observation may be related in part to social risk factors for HCV transmission, such as drug use, schistosomiases, and occupational exposure. However, the role of androgens in the gender bias must not be excluded (14). In this study, a novel modified multiplex nested PCR method was compared directly with a commercial INNO-LiPA assay method for HCV genotyping. Based on our results, the modified PCR method had a similar level of accuracy as the INNO-LiPA method but was simpler to use and significantly less expensive. In fact, all 70 typeable genotypes obtained by the modified PCR method matched those obtained from the INNO-LiPA method (100\% concordance). Two of the 3 samples that were nontypeable by modified multiplex PCR method were typeable by INNO-LiPA method: 1 was typed genotype 4, and the other was $4 \mathrm{c} / 4 \mathrm{~d}$. The genotype of 1 sample was nontypeable by either method, likely due to low viral load ( $\mathrm{r}=0.874, P<0.001)$. More importantly, the modified multiplex PCR method was appropriate for typing the prevalent HCV strains in our patient population. In fact, the HCV genotype 4 was detected in 65 out of 70 patients (92.86\%), supporting earlier studies (14, 31-36). However, our data also show that the contribution of genotype 4 to the study pool is not exclusive and that other genetically related genotypes exist in the population, confirming previous studies $(14,37,38)$. One cansuggest a deficiency of the multiplex PCR in subtyping genotype 4, but inclusion of more primers would be an unjustified burden on an already financially challenged health care system, in the absence of sufficient evidence to support clinical and therapeutic outcomes $(23,24)$.

One limitation of this multiplex method is the rarity of HCV genotypes other than genotype 4 in Egypt. However, in the original work by Idrees, 2008, the most prevalent genotype in Pakistan (3a) was detected with high frequency. Lower frequencies of other genotypes (3b,1a,3c,1b,2a,4,1c) were also observed. He suggested that due to higher sensitivity of the method, it may be useful for detecting other genotypes in regions of the world where they are predominant to validate its suitability for these genotypes (eg, 5a and 6a) (15). In conclusion, genotype 4 was the most prevalent genotype in our study. Based on our results, the new, modified multiplex nested PCR assay that we have presented is a sensitive, inexpensive alternative for HCV genotyping and is capable of reliably genotyping HCV RNA directly from clinical samples; thus, this novel assay can be used in routine diagnostic laboratories. Furthermore, INNO-LiPA may be useful as a second-line assay for genotyping samples that are indeterminate by multiplex PCR. This combination will lead to better patient evaluation, better treatment optimization, and a reduction in the spread of HCV. Moreover, the use of both genotyping assays in Egyptian patients might be valuable for large-scale genotyping projects on a national level.

\section{Acknowledgments}

None declared.

\section{Authors' Contribution}

None declared.

\section{Financial Disclosure}

None declared.

\section{Funding/Support}

This project was funded by a grant from Mr. Yousef Jameel, Yousef Jameel Science \& Technology Research Center (YJ-STRC) at the American University in Cairo (AUC) to Dr. Hassan Azzazy.

\section{References}

1. Nguyen MH, Keeffe EB. Prevalence and treatment of hepatitis $C$ virus genotypes 4, 5, and 6. Clin Gastroenterol Hepatol. 2005;3(10 Suppl 2):S97-S101.

2. Initiative for vaccine research. World Health Organization. 2007; Available From: www.who.int/entity/vaccine_research/ diseases/vector/en/

3. Abdel-Aziz F, Habib M, Mohamed MK, Abdel-Hamid M, Gamil F, Madkour S, et al. Hepatitis C virus (HCV) infection in a community in the Nile Delta: population description and HCV prevalence. Hepatology. 2000;32(1):111-5.

4. Egyptian Ministry of Health Annual Report. Egyptian Ministry of Health. 2007; Available From: http://www.mohp.gov.eg/default.aspx.

5. Germer JJ, Rys PN, Thorvilson JN, Persing DH. Determination of hepatitis $\mathrm{C}$ virus genotype by direct sequence analysis of products generated with the Amplicor HCV test. J Clin Microbiol. 1999;37(8):2625-30.

6. Halfon P, Trimoulet P, Bourliere M, Khiri H, de Ledinghen V, Couzigou P, et al. Hepatitis C virus genotyping based on 5' noncoding sequence analysis (Trugene). J Clin Microbiol. 2001;39(5):1771-3.

7. Verbeeck J, Stanley MJ, Shieh J, Celis L, Huyck E, Wollants E, et al. Evaluation of Versant hepatitis C virus genotype assay (LiPA) 2.0. JClin Microbiol. 2008;46(6):1901-6.

8. Forns X, Maluenda MD, Lopez-Labrador FX, Ampurdanes S, Olmedo E, Costa J, et al. Comparative study of three methods for genotyping hepatitis $C$ virus strains in samples from Spanish patients. J Clin Microbiol. 1996;34(10):2516-21.

9. Forns X, Bukh J. The molecular biology of hepatitis C virus. Genotypes and quasispecies. Clin Liver Dis. 1999;3(4):693-716, vii.

10. Okamoto H, Sugiyama Y, Okada S, Kurai K, Akahane Y, Sugai Y, et al. Typing hepatitis $C$ virus by polymerase chain reaction with type-specific primers: application to clinical surveys and tracing infectious sources. J Gen Virol. 1992;73(Pt 3):673-9.

11. Ohno O, Mizokami M, Wu RR, Saleh MG, Ohba K, Orito E, et al. New hepatitis C virus (HCV) genotyping system that allows for identification of HCV genotypes 1a, 1b, 2a, 2b, 3a, 3b, 4, 5a, and 6a. JClin Microbiol.1997;35(1):201-7.

12. Simmonds P, Holmes EC, Cha TA, Chan SW, McOmish F, Irvine B, et al. Classification of hepatitis $C$ virus into six major genotypes and a series of subtypes by phylogenetic analysis of the NS-5 region. J Gen Virol.1993;74(Pt 11):2391-9.

13. Stuyver L, Wyseur A, van Arnhem W, Lunel F, Laurent-Puig P, Pawlotsky JM, et al. Hepatitis C virus genotyping by means of 5'-UR/ core line probe assays and molecular analysis of untypeable samples. Virus Res. 1995;38(2-3):137-57.

14. El-Awady MK, Tabll AA, Atef K, Yousef SS, Omran MH, El-Abd Y, et al. Antibody to E1 peptide of hepatitis $C$ virus genotype 4 inhibits virus binding and entry to HepG2 cells in vitro. World J Gastroenterol. 2006;12(16):2530-5. 
15. Idrees M. Development of an improved genotyping assay for the detection of hepatitis $C$ virus genotypes and subtypes in Pakistan. J Virol Methods. 2008;150(1-2):50-6.

16. Kwok S, Higuchi R. Avoiding false positives with PCR. Nature 1989;339(6221):237-8.

17. Bouchardeau F, Cantaloube JF, Chevaliez S, Portal C, Razer A, Lefrere JJ, et al. Improvement of hepatitis C virus (HCV) genotype determination with the new version of the INNO-LiPA HCV assay. JClin Microbiol. 2007;45(4):1140-5.

18. Franciscus A. HCV Diagnostic Tools:Genotype, Subtype \& Quasispecies. HCSP Fact Sheet. 2010;2(2):1-3.

19. Simmonds P. Hepatitis C virus genotypes. In: Gallin J, Fauci A, Liang T, Hoofnagle J, editors. Hepatitis C, Biomedical Research Reports; 2000.

20. Kamal SM, Nasser IA. Hepatitis C genotype 4: What we know and what we don't yet know. Hepatology. 2008;47(4):1371-83.

21. Rapicetta M, Argentini C, Dettori S, Spada E, Pellizzer G, Gandin C. Molecular heterogeneity and new subtypes of HCV genotype 4 . Res Virol.1998;149(5):293-7.

22. Simmonds P, Bukh J, Combet C, Deleage G, Enomoto N, Feinstone $S$, et al. Consensus proposals for a unified system of nomenclature of hepatitis C virus genotypes. Hepatology. 2005;42(4):962-73.

23. Abdel-Hamid M, El-Daly M, Molnegren V, El-Kafrawy S, Abdel-Latif S, Esmat G, et al. Genetic diversity in hepatitis C virus in Egypt and possible association with hepatocellular carcinoma. J Gen Virol. 2007;88(Pt 5):1526-31.

24. Roulot D, Bourcier V, Grando V, Deny P, Baazia Y, Fontaine H, et al. Epidemiological characteristics and response to peginterferon plus ribavirin treatment of hepatitis $C$ virus genotype 4 infection. JViral Hepat. 2007;14(7):460-7.

25. Archer GT, Buring ML, Clark B, Ismay SL, Kenrick KG, Purusothaman K, et al. Prevalence of hepatitis C virus antibodies in Sydney blood donors. Med J Aust. 1992;157(4):225-7.

26. Frank C, Mohamed MK, Strickland GT, Lavanchy D, Arthur RR, Magder LS, et al. The role of parenteral antischistosomal therapy in the spread of hepatitis C virus in Egypt. Lancet. 2000;355(9207):887-91.

27. Kamel MA, Ghaffar YA, Wasef MA, Wright M, Clark LC, Miller FD. High HCV prevalence in Egyptian blood donors. Lancet. 1992;340(8816):427.

28. Lau JY, Davis GL, Kniffen J, Qian KP, Urdea MS, Chan CS, et al. Significance of serum hepatitis C virus RNA levels in chronic hepatitis
C. Lancet. 1993;341(8859):1501-4.

29. Tanaka E, Kiyosawa K, Sodeyama T, Hayata T, Ohike Y, Nakano Y, et al. Prevalence of antibody to hepatitis C virus in Japanese schoolchildren: comparison with adult blood donors. Am J Trop Med Hyg. 1992;46(4):460-4

30. Waked IA, Saleh SM, Moustafa MS, Raouf AA, Thomas DL, Strickland GT. High prevalence of hepatitis C in Egyptian patients with chronic liver disease. Gut.1995;37(1):105-7.

31. Abdulkarim AS, Zein NN, Germer JJ, Kolbert CP, Kabbani L, Krajnik KL, et al. Hepatitis $C$ virus genotypes and hepatitis $G$ virus in hemodialysis patients from Syria: identification of two novel hepatitis C virus subtypes. Am J Trop Med Hyg. 1998;59(4):571-6.

32. Blatt LM, Mutchnick MG, Tong MJ, Klion FM, Lebovics E, Freilich $\mathrm{B}$, et al. Assessment of hepatitis $\mathrm{C}$ virus RNA and genotype from 6807 patients with chronic hepatitis C in the United States. J Viral Hepat. 2000;7(3):196-202.

33. Chamberlain RW, Adams N, Saeed AA, Simmonds P, Elliott RM. Complete nucleotide sequence of a type 4 hepatitis $C$ virus variant, the predominant genotype in the Middle East. J Gen Virol. 1997;78(Pt 6):1341-7.

34. Dusheiko G, Schmilovitz-Weiss H, Brown D, McOmish F, Yap PL, Sherlock $S$, et al. Hepatitis $C$ virus genotypes: an investigation of type-specific differences in geographic origin and disease. Hepatology. 1994;19(1):13-8.

35. Morice Y, Roulot D, Grando V, Stirnemann J, Gault E, Jeantils V, et al. Phylogenetic analyses confirm the high prevalence of hepatitis $\mathrm{C}$ virus (HCV) type 4 in the Seine-Saint-Denis district (France) and indicate seven different HCV-4 subtypes linked to two different epidemiological patterns. J Gen Virol. 2001;82(Pt 5):1001-12.

36. Ray SC, Arthur RR, Carella A, Bukh J, Thomas DL. Genetic epidemiology of hepatitis C virus throughout egypt. J Infect Dis. 2000;182(3):698-707.

37. Cabot B, Martell M, Esteban JI, Piron M, Otero T, Esteban R, et al. Longitudinal evaluation of the structure of replicating and circulating hepatitis $\mathrm{C}$ virus quasispecies in nonprogressive chronic hepatitis C patients. J Virol. 2001;75(24):12005-13.

38. Genovese D, Dettori S, Argentini C, Villano U, Chionne P, Angelico $\mathrm{M}$, et al. Molecular epidemiology of hepatitis $\mathrm{C}$ virus genotype 4 isolates in Egypt and analysis of the variability of envelope proteins E1 and E2 in patients with chronic hepatitis. J Clin Microbiol. 2005;43(4):1902-9. 